\title{
Comunicação
}

[Communication]

\section{Anticorpos para Leptospira spp., Toxoplasma gondii e Neospora caninum em cães errantes albergados em canil privado}

\author{
[Antibodies to Leptospira spp., Toxoplasma gondii, and Neospora caninum in mongrel \\ dogs kept in private kennel] \\ C.C. Gonçalez ${ }^{1,2}$, A.C. Paes $^{1}$, H. Langoni ${ }^{1,3^{*}}$, R.C. Da Silva ${ }^{1,2}$, H. Greca ${ }^{1,2}$, L.G. Camossi ${ }^{1,2}$, \\ F.F. Guimarães ${ }^{1,2}$, L.S. Ullmann ${ }^{1,2}$ \\ ${ }^{1}$ Faculdade de Medicina Veterinária e Zootecnia \\ Distrito de Rubião Júnior, $\mathrm{s} / \mathrm{n}^{\circ}$ \\ 18618-000 - Botucatu, SP \\ ${ }^{2}$ Alunos de pós-graduação - FMVZ-UNESP - Botucatu, SP \\ ${ }^{3}$ Bolsista CNPq de Produtividade em Pesquisa-1A
}

A leptospirose é uma doença infectocontagiosa aguda, zoonótica, cosmopolita, que acomete animais domésticos, silvestres e roedores. Entre os animais domésticos, os cães são importantes fontes de infecção para o homem. Seus agentes pertencem à ordem Spirochaetales, família Leptospiraceae, gênero Leptospira e divididos em 12 genomespécies distintos, L. alexanderi, $L$. biflexa, L. borgpetersenii, L. fainei, L. inadai, $L$. interrogans, $L$. kirschneri, $L$. noguchii, $L$. santarosai, L. weilii, L. meyeri e L. wolbachii, com mais de 300 sorovares (Merien et al., 2005). A grande variedade de sorovares propicia a ocorrência de variações regionais, bem como nas espécies estudadas. Há uma predileção dos diferentes sorovares por determinadas espécies, e um hospedeiro pode se infectar por mais de um sorovar (Silva et al., 2006).

O cão tem grande importância na transmissão da leptospirose ao homem, por viver domiciliado, podendo ser importante fonte de infecção por excretar leptospiras pela urina por longo período de tempo, e o contato indireto com a água ou o solo contaminado com leptospiras são vias de transmissão comuns para o homem (Silva et al., 2006).

A toxoplasmose é causada pelo protozoário parasito intracelular obrigatório, Toxoplasma gondii. O gato é seu hospedeiro definitivo, e os animais homeotérmicos os hospedeiros intermediários. A infecção pode ocorrer pela ingestão de oocistos, que são eliminados nas fezes de felídeos, pelos cistos presentes em tecidos de hospedeiros intermediários e pela via transplacentária de taquizoítos. Os cães podem, ainda, atuar como sentinelas da infecção para o homem (Tenter, 1999).

A neosporose, causada pelo protozoário Neospora caninum, que apresenta o cão como hospedeiro definitivo, causa abortamentos endêmicos e epidêmicos e perdas neonatais em bovinos (McAllister et al., 1998). O cão também é hospedeiro intermediário, formando cistos em seus tecidos, à semelhança de equinos, bovinos, ovinos, caprinos e veados (Dubey, 1998). Não há relatos de casos da doença em humanos, embora já tenham sido detectados anticorpos para $N$. caninum em pacientes aidéticos (Lobato, 2006).

Desse modo, o presente estudo teve o objetivo de pesquisar anticorpos para Leptospira spp., $T$. gondii e $N$. caninum em cães errantes do município de Avaré, SP.

O município de Avaré, onde se realizou o estudo, localiza-se na região sudoeste do Estado de São Paulo, às margens do Rio Paranapanema, um

Recebido em 15 de março de 2009

Aceito em 20 de julho de 2010

*Autor para correspondência (corresponding author)

E-mail: hlangoni@fmvz.unesp.br 
grande volume de águas limpas. Foram estudados cães provenientes do Abrigo Piccolina, entidade que captura, recupera e disponibiliza para adoção cães abandonados pelas ruas do município desde outubro de 2003. Procedeu-se à colheita de sangue de 300 cães, sendo 180 fêmeas e 120 machos, todos castrados e mantidos em canis, com capacidade para cinco animais por baia, divididos de acordo com o estado geral e a idade.

Realizou-se a pesquisa de anticorpos para Leptospira spp. em amostras de soro pela soroaglutinação microscópica (SAM) (Manual..., 1995), utilizando-se 12 sorovares: Australis, Autumnalis, Bratislava, Canicola, Cynopteri, Copenhageni, Icterohaemorrhagiae, Hardjo, Djasman, Grippotyphosa, Pomona e Pyrogenes.

Os anticorpos para $T$. gondii foram pesquisados pelo método de aglutinação direta modificado (MAD) (Desmonts e Remington, 1980), e para pesquisa de anticorpos para $N$. caninum utilizouse a reação de imunofluorescência indireta (RIFI) (Conrad et al., 1993).

A resposta sorológica de aglutininas para Leptospira spp. foi de 9,3\% (28/300), apresentando maior importância os sorovares Bratislava, 35,7\% (10/28), seguido pelos sorovares Cynopteri, 17,9\% (5/28), Autumnalis, $14,3 \%$ (4/28), Copenhageni, 10,7\% (3/28) e Icterohaemorrhagiae, Canicola e Hardjo, com $7,1 \%(2 / 28)$ cada sorovar. Os títulos para os vários sorovares variaram entre 100 a 1600.

A discussão dos resultados é limitante devido às variáveis geográficas como clima, solo, estação do ano e sorovares, e pelo ponto de corte estabelecido. Silva et al. (2006) avaliaram 1000 cães no mesmo município, utilizando 24 sorovares, e atribuíram maior importância aos sorovares Castellonis (28,7\%), Autumnalis (19,1\%), Pyrogenes (17,6\%), Icterohaemorrhagiae (11\%) e Canicola $(9,6 \%)$.

Observou-se grande variação nas frequências para os diferentes sorovares. Salienta-se, ainda, a dificuldade na interpretação dos resultados sorológicos para leptospirose, pois podem ocorrer reações cruzadas entre os sorovares, e o fato de cães vacinados desenvolverem baixos títulos de anticorpos aglutinantes que podem persistir de um a três meses após a vacinação. $\mathrm{O}$ sorovar Icterohaemorrhagiae, muito importante em regiões de clima semelhante ao da região pesquisada, mostrou-se de menor importância no presente trabalho, com somente $7 \%$ de reagentes, diferente do resultado de Modolo et al. (2000), que obtiveram $119 / 775(15,4 \%)$ cães reagentes na cidade de Botucatu, com 40,4\% para Canicola e 34,5\% para Pyrogenes. Além disso, citaram a importância dos sorovares Copenhageni, Autumnalis e Bratislava, considerados emergentes ou reemergentes em outros países. No presente estudo, esses sorovares também foram importantes. Estes resultados mostram a importância da realização de inquéritos sorológicos como ações de vigilância contínua para se avaliar o papel dos cães na cadeia epidemiológica de transmissão da leptospirose.

Quanto à toxoplasmose, $78(26 \%)$ cães foram reagentes, sendo $10(3,3 \%)$ com título 16,41 $(13,7 \%)$ com título 64, e 27 (9\%) com título 256 . Para neosporose, dois cães $(0,7 \%)$ foram reagentes, um com título 25 e outro com título 100.

Bresciani et al. (2007), ao estudarem a prevalência do T. gondii em 108 cães de 63 diferentes canis em Araçatuba, SP, encontraram $25(23,1 \%)$ animais positivos, com títulos de 256 (44\%), o mais frequente, 64 (40\%), 1024 (12\%) e $4096(4 \%)$.

Varandas et al. (2001) testaram 295 amostras de soro canino para pesquisa de anticorpos para Toxoplasma gondii e $N$. caninum. Foram reagentes $151(51,2 \%)$ para $T$. gondii, e 17 $(5,8 \%)$ foram positivos tanto para neosporose quanto para toxoplasmose. Esses resultados mostram a grande dispersão desses agentes na população canina da região nordeste do estado de São Paulo, inclusive com ocorrência simultânea da infecção. Tal fato reforça o conceito de se considerar o cão como animal sentinela para a toxoplasmose, no que se refere à saúde pública.

Ocorrência da infecção foi maior de acordo com a idade (Tab. 1). Langoni et al. (2006), ao trabalharem com 780 amostras de soro, encontraram $258(33,1 \%)$ amostras positivas com título $16(52,6 \%)$, e de maior frequência, seguidos pelos títulos $64(42,4 \%)$ e $256(50,5 \%)$. Não houve diferença significativa quanto à ocorrência em machos e fêmeas, e a taxa de infecção foi maior com o aumento da idade dos 
animais. Utilizando também a MAD, o presente estudo revelou 78 (26\%) animais positivos, indicando a infecção na população canina estudada. Essa prevalência foi maior que a observada por Bresciani et al. (2007), no estado do São Paulo.

A frequência de infecção por $N$. caninum em $0,7 \%$ dos animais pode ser considerada baixa para as condições do presente estudo. Apesar de não se conhecer a procedência dos animais, sugere-se a não procedência da zona rural, onde a prevalência do $N$. caninum é maior, pois os cães podem se alimentar de restos de abortos, além da ingestão de oocistos presentes no meio ambiente.

A ocorrência de anticorpos para $N$. caninum em 10,7\% dos cães de áreas urbanas foi menor que os resultados obtidos em Araçatuba, SP, por Bresciani et al. (2007), com 17/108 (15,7\%) em $15 / 63(23,8 \%)$ canis. Jesus et al. (2006), ao trabalharem com cães domiciliados e errantes de Salvador e Lauro de Freitas, na Bahia, pela RIFI, detectaram $22(13,3 \%)$ de positividade em animais domiciliados e $28(11,2 \%)$ em animais errantes. A possibilidade de transmissão horizontal entre cães errantes na zona urbana e na zona rural pode ser maior devido à facilidade de ingestão de roedores, pássaros e outros animais que podem ser fontes de infecção. Outra hipótese é que cães errantes ou da zona rural são expostos mais frequentemente a ambientes contaminados com oocistos provenientes de cães infectados. Por outro lado, a transmissão vertical e a consequente criação de animais assintomáticos podem ser responsáveis pela manutenção da porcentagem de infecção na população canina.

Apesar de a positividade ser diferente para as três enfermidades pesquisadas, conclui-se que há dispersão dos agentes responsáveis pelas infecções leptospírica, toxoplásmica e por $N$. caninum na região estudada, aspecto relevante quanto à saúde pública, especialmente quanto à leptospirose e à toxoplasmose. Os resultados mostram ainda o papel do cão como animal sentinela na toxoplasmose, fato relevante no monitoramento das ações de saúde pública para o controle dessa zoonose na população humana.

Palavras-chave: cão, leptospirose, toxoplasmose, neosporose, sorologia

\begin{abstract}
The serological profile of 300 mongrel dogs of various ages and gender were investigated. Animals were captured in the streets and afterwards directed to a private kennel in Avaré city (SP) to search for leptospirosis, toxoplasmosis, and neosporosis. Blood samples were obtained from jugular or cephalic vein for the obtention of sera. The microscopic agglutination test (MAT) was used to leptospirosis. MAT detect the prevalence of $9.3 \%$. The most frequent reactant serovars were Bratislava (35.7\%), Cynopteri (17.9\%), Autumnalis (14.3\%), and Copenhageni (10.7\%), besides $7.1 \%$ to others serovars: Icterohaemorrhagiae, Canicola, and Hardjo. The modified agglutination test used for the diagnosis of toxoplasmosis showed $26 \%$ of positive animals, with titers varying from 16 to 256, with 16 in 3.3\%, 64 in 13.7\%, and 256 in $9 \%$ of the samples. To canine neosporosis, it was used the indirect fluorescent antibody test, and two animals $(0.7 \%)$ demonstrated antibodies with titers 25 and 100. The results show the participation of the animals in the epidemiological chain of the researched diseases.
\end{abstract}

Keywords: dog, leptospirosis, toxoplasmosis, neosporosis, serology

\section{REFERÊNCIAS BIBLIOGRÁFICAS}

CONRAD, P.A.; SVERLOW, K.W.; ANDERSON, M.L. et al. Detection of serum antibody responses in cattle with natural or experimental Neospora infections. J. Vet. Diagn. Invest., v.5, p.572-578, 1993.
DESMONTS, G.; REMINGTON, J.S. Direct agglutination test for diagnosis of Toxoplasma infection: method for increasing sensitivity and specificity. J. Clin. Microbiol., v.11, p.562-568, 1980.

DUBEY, J.P. Advances in the life cycle of Toxoplasma gondii. Int. J. Parasitol., v.28, p.1019-1024, 1998. 
BRESCIANI, K.D.S.; COSTA, A.J.; NUNES, C.M. et al. Ocorrência de anticorpos contra Neospora caninum e Toxoplasma gondii e estudo de fatores de risco em cães de Araçatuba - SP. Ars. Vet., v.23, p.40-46, 2007.

JESUS, E.E.V.; SANTOS, P.O.M.; BARBOSA, M.V.F. et al. Frequência de anticorpos antiNeospora caninum em cães nos municípios de Salvador e Lauro de Freitas, Estado da BahiaBrasil. Braz. J. Vet. Res. Anim. Sci., v.43, p.5-10, 2006.

LANGONI, H.; MODOLO, J.R.; PEZERINO, S.B. et al. Serological profile of anti-Toxoplasma gondii in apparently healthy dogs of the city of Botucatu, São Paulo, State Brazil. J. Venom. Anim. Toxins Incl. Trop. Dis., v.12, p.142-148, 2006.

LOBATO, J.; SILVA, D.A.O.; MINEO, W.P. et al. Detection of Immunoglobulin $\mathrm{G}$ antibodies to Neospora caninum in humans: high seropositivity rates in patients who are infected by human immunodeficiency virus or have neurological disorders. Clin. Vaccine Immunol., v.13, p.84-89, 2006.

MANUAL de leptospirose. 2.ed. Brasília, DF: FUNASA, 1995. 98p.

McALLISTER, M.M.; DUBEY, J.P.; LINDSAY, D.S. et al. Dogs are definitive hosts of Neospora caninum. Int. J. Parasitol., v.28, p.1473-1478, 1998.
MERIEN, F.; PORTNOI, D.; BOURHY, P. et al. A rapid and quantitative method for the detection of Leptospira species in human leptoapirosis. FEMS Microbiol. Lett., v.249, p.139-147, 2005.

MODOLO, J.R.; LANGONI, H.; SHIMABUKURO, F.H. et al. Inquérito soroepidemiológico para leptospirose canina, no município de Botucatu - SP. In: CONGRESSO BRASILEIRO DE VETERINÁRIA, 27., 2000, Águas de Lindóia. Anais... Águas de Lindóia, 2000. p.95.

SILVA, W.B.; SIMÕES, L.B.; LOPES, A.L.S. et al. Avaliação de fatores de risco de cães sororreagentes à Leptospira spp. e sua distribuição espacial, em área territorial urbana. Braz. J. Vet. Res. Anim. Sci., v.43, p.783-792, 2006.

TENTER, A.M. Current knowledge on the epidemiology of infections with Toxoplasma. Tokai J. Exp. Clin. Med., v.23, p.391, 1999.

VARANDAS, N.P.; RACHED, P.A.; COSTA, G.H.N. et al. Frequência de anticorpos antiNeospora-caninum e anti-Toxoplasma gondii em cães da região nordeste do Estado de São Paulo. Correlação com neuropatias. Semin. Cienc. Agrar., v.22, p.105-111, 2001. 